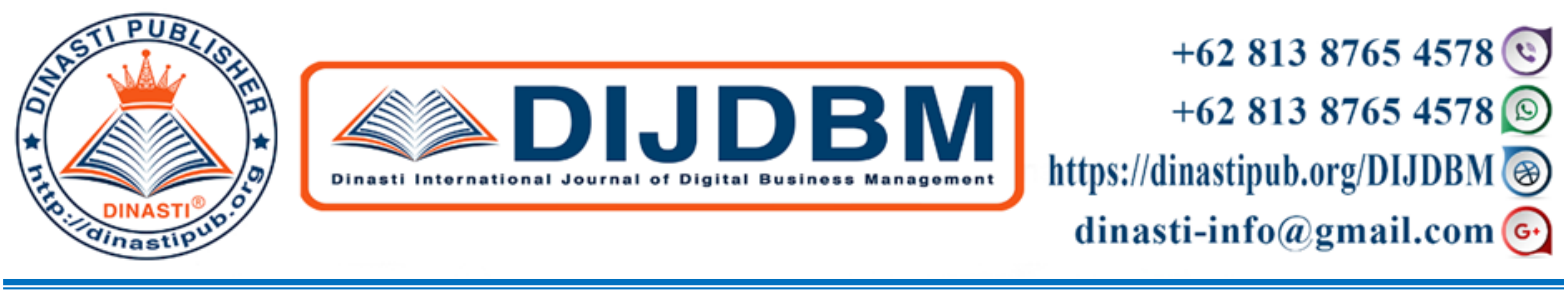

\title{
IMPLEMENTATION OF GOOD CORPORATE GOVERNANCE AT PT AXA MANDIRI FINANCIAL SERVICES
}

\section{Hudriatul Hotimah}

Mercu Buana University, Jakarta, Indonesia

ARTICLE INFORMATION

Received: $29^{\text {th }}$ May 2020

Revised: $20^{\text {th }}$ June 2020

Issued: $23^{\text {th }}$ August 2020

Corresponding author:

first author

E-mail:

hudriatulhotimah@ymail.com

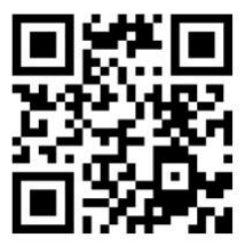

DOI:10.31933/DIJDBM
Abstract: Good Corporate Governance (GCG) is a system that organizes and controls a company so that it can form added value for all stakeholders. This study aims to determine the application of GCG at PT AXA Mandiri Financial Services (AMFS) which is a joint venture Conventional Life Insurance company between PT Bank Mandiri (Persero) Tbk and National Mutual International Pty. Limited (AXA). The research method used is descriptive qualitative. The results of this study indicate that PT AMFS has implemented GCG in an integrated manner in all business processes. This is evidenced by the transformation in 10 line areas, namely digital services, distribution, health and protection, human resources and culture, information technology systems, data, efficiency, customer experience, and offers (documents and products). PT AMFS also applies the Three Lines of Defense principle to an internal control system that is integrated with risk management. The main line of defense is the directors and all employees of PT AMFS. Second, risk management, compliance and law. Third, internal and external audit.

Keywords: Good Corporate Governance, AXA Mandiri Financial Services, Life Insurance

\section{INTRODUCTION}

The implementation of GCG (Good Corporate Governance) is a benchmark in supporting the company's growth and development. Good Corporate Governance has an important role in running the company's ecosystem which later will make the company more healthy (Ali H, 2020). Companies in carrying out business activities, must pay attention to Good Corporate Governance, both internal and external to the Company. For this reason, a system is needed to control Good Corporate Govenance so that the desired company goals are achieved. 
Good Corporate Governance (GCG) is a process of managing company performance to create sustainable added value in the long term, (Zarkasyi, 2008). Good Corporate Governance is a key element in creating economic efficiency, which consists of a series of relationships between the board of commissioners, company management, shareholders and all corporate stakeholders. Good Corporate Governance also creates a structure that can facilitate the determination of company targets, and as a means of determining appropriate techniques for monitoring performance (Darmawati, et. Al, 2004)

The development of the company explains that management is not only the management process running effectively and efficiently. In implementing Good Corporate Governance (GCG) new instruments are needed that are useful to ensure that the management that is run by the company is running well or not. Two things that are of concern in carrying out the concept of GCG, namely one right from shareholders is very important to obtain information which consists of correct and correct information. The second is that the company has an obligation to make disclosures that produce results accurately, timely and transparently and is linked to company performance information, related ownership, and stakeholders. The results of studies conducted by various research institutions indicate that there is still a lack of understanding of the importance of CGC and strategy in implementing GCG principles by companies and business people in Indonesia. As well as the important role of organizational culture in influencing the application of CGC in Indonesia (Agussalim M, Ndraha H, and Ali H 2020).

PT AXA Mandiri Financial Services (AMFS), hereinafter referred to as "the Company", realizes the importance of the meaning of the Implementation of Good Corporate Governance as a tool to continuously increase value and long-term business growth, not only for Shareholders but also for all stakeholders interests (Stakeholders). A company in carrying out its business is required to run the business with full trust and transparency.

The Board of Commissioners mandates the Board of Directors to improve the quality of the implementation of Good Corporate Governance (GCG) in daily operational activities. Therefore, the Board of Commissioners supports the effort to socialize and apply the rules covered by the GCG Guidelines, Code of Ethics and the company's values to all employees. In an effort to harmonize the implementation of GCG in accordance with best practices, AXA Mandiri continues to work closely with regulators including the Financial Services Authority (OJK) and associations including the Indonesian Life Insurance Association (AAJI) and the Insurance Association Syariah Indonesia (AASI).

In this way, in the future AXA Mandiri will be able to record better performance in the implementation of Corporate Governance as regulated in applicable laws and regulations.

Based on this background, the research conducted to analyze whether the implementation of good corporate governance in PT AXA Mandiri Financial Services has been carried out in accordance with the theory and principles - principles. Implementation of Good Corporate Governance has an influence on brand image and corporate image to increase the value of the company to all stakeholders. 


\section{LITERATURE REVIEW}

\section{Definition of Good Corporate Governance}

Governance is a series of processes of social and political interaction carried out between the government and the community in all fields that have a link between the interests of the community and interventions by the government in the fulfillment of the prevailing interests. Governance can also be interpreted as a mechanism, process, and institution through citizens in interpreting and explaining the interests of institutional interests, mediating the differences that occur and using their rights and obligations (Kooiman, 2009). In applying the principles of Corporate Governance ethics and norms become the main landscape. Some definitions of Corporate Governance include:

1. Corporate Governance is a set of rules that are very functioning in determining the relationship between shareholders, management, government, creditors, and employees as well as holders who have other internal and external interests that can often relate to applicable rights and obligations, or it can be said that the system being implemented plays a role in directing and controlling the company. (Forum for Corporate Governance in Indonesia / FCGI)

2. Corporate Governance is a process and structure that can be used by SOE organizations to improve the achievement of business success and corporate accountability in order to realize the values set by the company. Shareholders in this case are very important in taking into account the interests of other stakeholders which are based on legislation and ethical values (SOE Ministerial Decree Number Kep-117 / M-MBU / 2002).

Governance in general has a term as a system of control and regulation of the company, or can be interpreted more aimed at actions taken by company executives in minimizing the loss of other stakeholders. Good Corporate Governance is very closely related to people (morality), work ethics, and good work principles. Corporate governance which is considered bad can be indicated as one of several causes of Indonesia's political economic crisis. The growth of governance that occurs in companies is phenomenal, social strength and organizational influence have a balanced contribution in taking responsibility to balance their own interests. The governance that is carried out by the company is closely related to the way or steps in which the financial supplier to the company to ensure that he still gets a return on investment (Amanah, Dhiana and Fathoni 2018). The mechanism implemented has a device in which outside investors protect themselves against expropriation by managers and controlling shareholders. The guideline in doing this is the company's mechanism to determine which should reduce agency costs and better align the interests of the board and suppliers of capital (Dimopoulos and Wagner 2016)

Corporate governance is used as a legal system, rules and factors that can control the operation of an organization. Various kinds of norms and laws that have been applied have formed the relationship between the board of directors, shareholders, and managers in resolving agency conflicts (Kalemli-Ozcan and Fan 2016). Problems that often occur in corporate governance, such as the greatness of the CEO, the competence of the Board of Directors, and the interests of shareholders are important only because with this, some organizations get into trouble. In discussing the glory and prosperity, very few people think 
about this problem. Structures and mechanisms that shape corporate governance have very serious attention in the world (Widodo D, Silitonga P, and Ali H 2020). Acceptance made by stakeholders is very specific based on context. In this context, the superiority that occurs is driven by the problem of agency and investor activism, while in other contexts the thing that happens is driven by the desire to attract foreign investment and easily obtain national and international legitimacy. Corporate governance in this case is very important because there is a part of institutional infrastructure (Examples such as laws, regulations, institutions and enforcement mechanisms) that can underlie the success of good economic performance (Chen, Qi and Schlagenhauf 2018).

Business practices carried out by companies can be said to be healthy if the implementation of organizational functions that are carried out based on the principles of good management (good corporate governance) in order to improve the provision of quality and sustainable services. Good corporate governance (GCG) is a concept in increasing transparency and accountability that has a purpose to ensure that the goals set can be achieved by using resources as efficiently as possible (Dallas 2017). GCG in another sense is a system that can regulate and control the company in creating value added which will ultimately be useful for all stakeholders. The concept of GCG in Indonesia has a meaning as a concept of good corporate management that is based on principles that hold firm in morality, ethics, and performance.

\section{Principles of Good Corporate Governance}

The following are the governance principles contained in OJK regulations governing GCG in insurance companies:

\section{Openness}

i.e., in the openness of the process, the method taken in deciding and openness in disclosing and providing valid information about the Company in the insurance industry, which is easily accessible to all people in the company in accordance with the provisions of the legislation in the insurance sector as well as standards, principles, and practices the implementation of a healthy insurance business entity.

\section{Accountability}

i.e. explains the function of implementing organ employee accountability in insurance companies so that the performance of insurance companies can run fairly, transparently, effectively and efficiently.

3. responsibility

namely the suitability of the management of the Company in the insurance industry by referring to the laws and regulations in the field of insurance and the value of business ethics which includes principles, standards and implementation of good insurance business operations.

4. independence (independency)

i.e. conditions where the company in the insurance industry is managed independently, professionally and free from personal interests that affect or suppress any party that is not in accordance with the laws and regulations in the field of insurance and business 
ethics values that include principles, standards and implementation of the implementation good insurance business.

5. equality and fairness

namely equal and fair equality in the fulfillment of the rights of the Stakeholders arising based on business agreements as well as legal regulations in the field of insurance and business ethics values that include principles, standards and implementation of good insurance business operations

\section{Benefits of Good Corporate Governance}

The implementation of good corporate governance in a company not only protects the rights of investors but also has many benefits and advantages for the company and also other parties that have a relationship with the company both directly and indirectly. Many of the benefits gained by implementing good corporate governance in the company are as follows:

1. By implementing good corporate governance in companies can minimize agency costs, the costs arising from the delegation of authority to management, including other costs such as the use of resources in the company by management for personal affairs or supervision of management behavior.

2. The company can minimize the cost of capital, which is the cost of capital that is charged if the company submits a loan to the bank or creditor. This is the result of managing a well-managed and healthy company that creates a positive reference for creditors.

3. By doing good corporate governance in the decision making process will produce optimal decisions, so as to increase the level of efficiency and can create a healthier work culture. These three things will create a positive influence on company performance, and company performance will increase. (Sakai \& Asaoka 2003; Balck et al., 2003).

4. By implementing Good corporate governance is proven to be able to avoid or minimize the misuse of authority by company officials in managing the company. This certainly will reduce the possibility of losses for the company and stakeholders from these actions. Chtourou et al. (2001) states that the application of consistent corporate governance principles will reduce the possibility of implementing performance management (earnings management) which can result in fundamental values in a company not recorded in its financial statements.

5. In the eyes of investors the value of the company will increase confidence in the management of the company. As investor confidence in the company increases, it will facilitate the company in requesting additional funds for various company needs, especially for expansion purposes. The results of research conducted by McKinsey \& Company (2002) prove that more than $70 \%$ of institutional investors are willing to pay more (reaching 26-30\% more expensive) shares of companies that implement good corporate governance compared to companies whose implementation is still doubtful.

6. For shareholders, an increase in performance will affect the increase in the value of shares and also the value of dividends to be received by shareholders. For the state, this will also have an impact on increasing the amount of tax that will be received from 
company payments, which automatically affects the increase in state revenue from the tax sector.

7. In implementing corporate governance, employees are one of the stakeholders that must be managed as best as possible by the company so that they can motivate and increase employee job satisfaction. So that the increase will have an impact on productivity and a sense of belonging to the company.

8. The optimal implementation of corporate governance can increase stakeholders' trust in the company so that the company's positive image will increase.

9. In implementing optimal corporate governance can improve the quality of corporate financial reports in a good and informative manner. So that management is not possible to engineer financial statements. According to research results from Beasley et al. (1996) and Abbott et al. (2000) show that by implementing good corporate governance can improve the quality of financial statements

\section{The Aim of Good Corporate Governance}

It is hoped that the implementation of the Corporate Governance mechanism will be able to suppress problems arising from the agency problems. This will create a sense of security from all shareholders or other investors that their rights are respected and protected. Management or majority shareholders who have a voice to control the company must act within the boundaries of the existing rules and may not force anything beyond the capabilities or limitations of information owned by investors. Mutual trust between investors and company managers who refer to corporate governance guidelines is expected to encourage increased company performance. This will certainly benefit investors and company managers.

In addition, awareness of the implementation of Good Corporate Governance will encourage corporate transparency. Investors will appreciate the information presented in full to help evaluate the company's performance as well as the company's prospects in the future. Even so the role of shareholders can increase awareness about corporate governance and know the importance of the value of company shareholders to achieve the company's vision.

In implementing Good Corporate Governance, it is able to prevent fraudulent actions such as insider trading, internal acquisitions and special relationship transactions that harm minority shareholders. In addition, the application of corporate governance can encourage the creation of an atmosphere of fair competition. If all companies can implement Good Corporate Governance, it is expected that the performance of companies in Indonesia can experience an increase. From these actions can affect investors' views of investment in Indonesia.

The implementation of the Good Corporate Governance system is expected to be able to increase added value for all stakeholders that have the following objectives:

a. Improving efficiency, effectiveness, with a sustainable system of an organization that can contribute to the creation of the welfare of the company's stakeholders and is a solution in facing the challenges of the organization in the future.

b. Increase the legitimacy of the organization being managed by referring to the principles of governance in the company. 
c. Fulfill and safeguard the rights and obligations of stakeholders.

In applying the value of Corporate Governance, the Company uses an approach of a strong attitude of confidence in the benefits of implementing Corporate Governance. Based on a strong sense of trust, it can foster a high enthusiasm to carry out according to international standards. To ensure that Corporate Governance is optimally implemented in each line and organ of the company, in its preparation the Company uses various references to be used as guidelines for all employees. In addition to internal references, the Company also adopts applicable laws and regulations. In terms of applying GCG principles, the application of Governance will be effective by prioritizing the principle of compliance in business activities, which is exemplified by the management and then followed by all employees. Through consistent, decisive and continuous application of all business people.

\section{Factors Affecting Implementation of Good Corporate Governance}

Quoted from (www.mandiri.com), the conditions for successful GCG implementation have two factors namely external factors and internal factors, which are mentioned as follows:

a. External factors

1. Have a good legal system.

2. Support the implementation of GCG from the public sector / government agency.

3. Have examples of proper GCG implementation (best practices).

4. Building a value system that supports the implementation of GCG in the community.

5. Having an anti-corruption attitude in operating companies, followed by improving the quality of education and expanding employment opportunities.

b. Internal factors

1. Having a corporate culture that supports the implementation of GCG.

2. Regulations and policies issued by the company refer to the implementation of GCG values.

3. Management of corporate risk control is based on GCG standard rules.

4. Having an effective audit system (inspection) at the company.

5. The existence of information disclosure attitude to the public.

\section{Mekanism of Good Corporate Governance}

Management of the company or also referred to as corporate governance, has a fairly broad definition. In a narrow sense, corporate governance is closely linked with managers, directors, auditors and shareholders. while broadly, corporate governance includes a combination of laws, regulations, registration rules and personal practices that can increase company value, can make company performance more efficient, create greater profits, and meet the expectations of the general public and comply with applicable law. The existence of these elements has functions and responsibilities related to the implementation of good corporate governance.

Additional elements to complete the application of GCG (Agoes, 2011: 109), namely:

1. Size of the Board of Commissioners

According to the Limited Liability Company Law Number 40 Year 2007 paragraph 6, the board of commissioners explains as follows: 
"The Board of Commissioners is the organ in charge of carrying out general and / or special supervision in accordance with the articles of association and giving advice to directors"

The National Governance Policy Committee (KNKG) (2006) describes the board of commissioners as follows:

"The Board of Commissioners is part of the corporate structure that has the duty and responsibility on an ongoing basis to supervise and provide advice in the form of criticism or constructive suggestions to the board of directors and ensure that the company has implemented optimal governance. However, the board of commissioners may not participate in operational decision making "

Sembiring (2005) explains that the size of the board of commissioners is as follows:

"The size of the board of commissioners is the total of all members of the board of commissioners in a company"

From this explanation from the Limited Company Law No.40 of 2007 paragraph 2, KNKG in 2006 and according to Sembiring in 2005, the conclusion was that the size of the board of commissioners is the total of all members of the board of commissioners who supervise the directors in carrying out the company's business activities.

2. Independent Board of Commissioners

Tunggal (2009: 79) explains that independent commissioners namely: "Independent commissioners are members of the board of commissioners determined based on the results of the GMS from parties who are not affiliated with major shareholders."

Agoes and Ardana (2014: 110) argue that an Independent commissioner namely: "An independent commissioner and director is someone who is chosen as a representative of minority shareholders and that the party does not have the capacity to represent any party and is appointed solely based on background knowledge, experience and professional expertise it has that aims to carry out tasks in the interests of the company ".

The National Committee on Governance Policy (2006) explains that independent commissioners namely: "Independent Commissioners are members of the board of commissioners who are not affiliated with management and other members of the board of commissioners as well as shareholders who are free from business relationships or other interests that can affect the ability of their independent attitude or carry out his duty for the benefit of the company. "

From the expert opinion described above namely Tunggal (2009: 79), Agoes and Ardan (2014: 110) and the National Committee on Dividend Policy (2006) it can be concluded that the independent board of commissioners is a member of the board of commissioners that is not affiliated with management, shareholders, and other members of the board of commissioners.

1. Institutional Ownership

According to Widarjo (2010: 25) Institutional Ownership namely: "Institutional Ownership is a condition when an institution has a stake in a company. These institutions are in the form of government institutions, private and foreign institutions. " 
According to Masdupi (2005) explains that: "Institutional Ownership is a measure of shares owned by institutions at the end of the year measured in percentage of shares owned by institutional investors in a company".

While Thesarani (2016) explains that: "Institutional Ownership is a measure of institutional ownership at the end of the year measured in percentage of shares owned by institutional investors in the company."

From the expert opinion above namely Widarjo (2010: 25), Masdupi (2005), and Theserani (2016), it can be concluded that institutional ownership is a measure of shares owned institutionally in a company at the end of the year.

\section{Managerial Ownership}

Understanding managerial ownership According to Tjeleni (2013), as follows: "Managerial ownership is a situation where the manager owns the company's shares or in other words the manager as well as a shareholder".

According to Gibson (2003) the notion of managerial ownership is: "The amount of share ownership by the management of all share capital of the company being managed."

Meanwhile, according to Phitaloka (2009: 30), Managerial ownership: "Managerial ownership shows the dual role of a manager, namely acting also as a shareholder"

Of the three definitions above from Tjeleni (2013), Gibson (2003), and Phitaloka (2009: 30) it can be concluded that managerial ownership is the total share ownership by the management of the total share capital of the company being managed.

3. Audit Committee

According to Tugiman (1995) An audit committee is: "An audit committee is an audit team chosen by company management to inspect certain jobs or to carry out specific tasks or members of the client company's Board of Commissioners responsible for forming auditors in maintaining the level of independence of management."

Whereas Arents (2010) defines the audit committee as: "The audit committee consists of several teams or groups of people who are not part of the company's management. The establishment of the audit committee aims to mediate between the auditor and company management if at any time a dispute occurs. "

Regulation Number IX.1.5 in the attachment to the Decree of the Chairman of Bapepam Number: Kep-29 / PM / 2004 states that: "The Audit Committee is a committee formed by the board of commissioners in order to help carry out its duties and functions".

Of the three definitions above from Tugiman (1995), Gibson (2003), Arents (2010) and Rule Number IX.1.5 in the appendix to the Decree of the Chairman of Bapepam Number: Kep-29 / PM / 2004 it can be concluded that the audit committee is a member of the committee formed by the board of commissioners that collaborates in carrying out the duties and functions of the board of commissioners, one of the tasks of which is ensuring the effectiveness of internal system control and the audit committee is also responsible to the board of commissioners. 


\section{RESEARCH METHODS}

In this study, researchers used a descriptive qualitative research type. According to Sugiyono (2008), qualitative research is research that is used to analyze data by describing or describing data that has been collected as it is without intending to make conclusions that apply to the public or generalizations. This research uses observations that are described descriptively by using the analytical skills of researchers who are supported by theoretical studies from various sources.

In this study, the subject of the study was PT AXA Mandiri Financial Services, which is engaged in conventional life insurance. This research will describe the implementation of Good Corporate Governance at PT AXA Mandiri Financial Services. While the object of research is the implementation of the principles of Good Corporate Governance at PT AXA Mandiri Financial Services.

Retrieval of data sources using purposive sampling techniques, namely how to take data samples with special characteristics in accordance with the purpose of the study.

The type of data used is qualitative data type, i.e.

\section{Primary Data}

Primary data sources are data obtained directly from research subjects, in this case the researcher obtained data or information directly using predetermined instruments (Purhantara, 2010). Primary data in this study were obtained through interviews and identification of the application of the principle Good Corporate Governance at PT AXA Mandiri Financial Services.

\section{Secondary Data}

Secondary data is data obtained in the form of ready-made (available) publications and information released from organizations or companies, and can also be interpreted as data sources beyond words and actions, namely written sources. Moleong further explained that the data in terms of written sources can be divided into sources from books, scientific magazines, personal documents and official documents. (Kotler and Keller, 2007, p.177). In this study, researchers obtained secondary data information that can be accessed through various media such as company websites, journals, literature, company regulation books, Good Corporate Governance and corporate governance

\section{RESULT AND DISCUSSION}

\section{Company Profile}

AXA Mandiri consists of life insurance business, namely PT AXA Mandiri Financial Services and general insurance business, namely PT Mandiri AXA General Insurance. Both are joint ventures between PT Bank Mandiri (Persero) Tbk and AXA Group. PT AXA Mandiri Financial Services (AMFS) is a Conventional Life Insurance company known as an insurance company with a service culture. The location of PT AXA Mandiri Financial Services is on Jl. Prof. Dr. Satrio Kav. 18, Kuningan City, Jakarta 12940, Indonesia.

PT. AXA Mandiri Financial Services began operating on October 28, 1991 based on Deed No. 179 dated 30 September 1991 made before the Notary Muhani Salim, SH as agreed with the Decree of the Minister of Justice of the Republic of Indonesia Number C2- 
6144.HT.01.01.TH.91, PT Asuransi Jiwa Staco Raharja became the forerunner of PT AXA Mandiri Financial Services ("AXA Mandiri ") now. The company that holds a life insurance business license continues to experience management development, until 30 April 2002 management was taken over and changed its name to PT Asuransi Jiwa Mandiri based on Deed No. 17 dated March 25, 2002 made before the Notary Muhani Salim, SH as approved through the Decree of the Minister of Justice and Human Rights of the Republic of Indonesia Number C-07463 HT.01.04.TH.2002 dated April 30, 2002. PT Asuransi Jiwa Mandiri changed the business license in February 11, 2004 focused on financial strength and expertise in banking and insurance. With the change in business license, PT Asuransi Jiwa Mandiri changed its name to PT AXA Mandiri Financial Services.

\section{AXA Mandiri Business Field}

In general, the business fields of AXA Mandiri can be categorized as follows:

- Providing retail insurance products with a combination of insurance and investment (unit link), for retail customers to meet the needs of old age funds, education funds or other financial goals.

- Providing traditional insurance products that provide protection benefits for life and health insurance that are complemented by additional protection (riders), for example through Mandiri Jiwa Sejahtera and Mandiri Health Insurance products.

- Provides insurance protection for customers who have credit cards, savings, consumer loans and micro credit customers of Bank Mandiri and other companies, subsidiaries of Bank Mandiri.

- Providing Corporate Solution insurance products for company employees, including Mandiri Corporate Health Plan, Mandiri Corporate Savings, and Mandiri Corporate Life Plan

\section{Products of AXA Mandiri}

A. Products marketed through the bancassurance channel consist of:

1. Traditional products;

(a) For protection purposes

(1) Mandiri Jiwa Sejahtera Insurance

This product provides protection against the risk of life uncertainty, such as death and accidents.

(2) Priority Mandiri life insurance

This product provides life protection benefits against the risk of death.

(b) For the purpose of health protection.

(1) Mandiri Health Insurance Insurance

This product provides health risk protection benefits by reimbursing the daily costs of hospital inpatients, reimbursing surgical costs, to the cost of transportation to the hospital.

(2) Mandiri Health Prima Insurance 
This product provides health protection benefits through access to health services in leading hospitals and doctors throughout the world and reimbursement of inpatient fees and international emergency medical assistance at any time (24 hours x 7 days).

2. Unit Link Products;

(a) Products with regular premium payments;

(1) Mandiri Elite Plan Insurance

This product provides comprehensive protection with features that will optimize life protection and investment returns.

(2) Mandiri Prosperous Insurance established

This product provides comprehensive life protection benefits by investing in future financial planning when experiencing the risk of life uncertainty.

(3) Mandiri Welfare Intelligent Insurance

This product provides life protection benefits accompanied by investments that help financial planning to ensure adequate education funding for children in case something happens to the Insured.

\section{Company Values}

The company values of PT AXA Mandiri Financial Services are as follows:

- Available

The main cultural value which refers to efforts to always be ready and to be proactive, and willing to listen and be open.

- Reliable

Values that prioritize commitment to be reliable, competent and responsible and are committed to always providing the best solutions and results.

- Attentive

Values that align the mind with the behavior of thinking, saying and acting praiseworthy; in accordance with the principle of morality which shows the existence of character and character; and able to work together and be responsive.

- Easy

Cultural values that promote innovation in creative, proactive, and practical attitudes and behaviors and try to develop new ideas by thinking beyond limits, easily communicating, effective and simple.

\section{Implementation of Good Corporate Governance At Company}

AXA Mandiri is committed to conducting its business in accordance with the highest ethical standards in terms of honesty, integrity and fairness. This commitment is designed not only to ensure compliance with applicable laws and regulations in the various jurisdictions in which we operate, but also to obtain and maintain the ongoing trust of our customers, shareholders, employees, business partners and all stakeholders. This is very important for the long-term success of AXA Mandiri. 
The Board of Commissioners mandates the Board of Directors to improve the quality of the implementation of Good Corporate Governance (GCG) in daily operational activities. Therefore, the Board of Commissioners supports the effort to socialize and apply the rules covered by the GCG Guidelines, Code of Ethics and the company's values to all employees. In an effort to harmonize GCG implementation in accordance with best practices, AXA Mandiri continues to work closely with regulators including the Financial Services Authority (OJK) and associations including the Indonesian Life Insurance Association (AAJI) and the Indonesian Sharia Insurance Association (AASI).

PT AXA Mandiri Financial Services, a joint venture of Bank Mandiri and AXA Group, transforms 10 areas, namely digital services, distribution, health and protection, human resources and culture, information technology systems, data, efficiency, customer experience, and offers ( documents and products). This transformation is carried out at the same time to create value for stakeholders for long-term prospects.

In the implementation of GCG, according to Ni Nyoman Trinasari as the Chief of Operation of PT AXA Mandiri Financial Services, AXA Mandiri applies the Three Lines of Defense principle to an internal control system integrated with risk management. The main line of defense is the directors and all AXA Mandiri employees. Second, risk management, compliance and law. Third, internal and external audit.

In this way, in the future AXA Mandiri will be able to record better performance in the implementation of Corporate Governance as regulated in applicable laws and regulations.

\section{CONCLUSIONS AND SUGGESTION}

The conclusion from the results of a literature study conducted by the author, the following conclusions can be drawn:

The Board of Commissioners mandates the Board of Directors to improve the quality of the implementation of Good Corporate Governance (GCG) in daily operational activities. Therefore, the Board of Commissioners supports the effort to socialize and apply the rules covered by the GCG Guidelines, Code of Ethics and the company's values to all employees. In an effort to harmonize the implementation of GCG in accordance with best practices, AXA Mandiri continues to work closely with regulators including the Financial Services Authority (OJK) and associations including the Indonesian Life Insurance Association (AAJI) and the Insurance Association Syariah Indonesia (AASI).

PT AXA Mandiri Financial Services, a joint venture of Bank Mandiri and AXA Group, transforms 10 areas, namely digital services, distribution, health and protection, human resources and culture, information technology systems, data, efficiency, customer experience, and offers ( documents and products). This transformation is carried out at the same time to create value for stakeholders for long-term prospects.

In the implementation of GCG, according to Ni Nyoman Trinasari as the Chief of Operation of PT AXA Mandiri Financial Services, AXA Mandiri applies the Three Lines of Defense principle to an internal control system integrated with risk management. The main line of defense is the directors and all AXA Mandiri employees. Second, risk management, compliance and law. Third, internal and external audit. 


\section{REFFERENCES}

Agoes. 2011. Auditing Petunjuk Praktis Pemeriksaan Akuntan oleh Akuntan Publik. Jilid 1. Salemba Empat, Jakarta

Ali, Hapzi. 2020. Modul Business Ethics \& GG Panduan Etika Bisnis Perusahaan. Universitas Mercu Buana.Jakarta.

Amanah, N., Dhiana, P., \& Fathoni, A. 2018. The Influence of Dividend Policy, Debt

Chen, D., Qi, S., \& Schlagenhauf, D. (2018). Corporate income tax, legal form of organization, and employment. American Economic Journal: Macroeconomics, 10(4), 270-304.

Dallas, L. L. (2017). Is There Hope for Change: The Evolution of Conceptions of Good Corporate Governance. San Diego L. Rev., 54, 491.

Dimopoulos, T., \& Wagner, H. F. 2016. Corporate Governance and CEO Turnover Decisions. Swiss Finance Institute Research Paper, (12-16).

Hendra, Dimaz. 2018. Praktik GCG di Anak Usaha Bank Mandiri. https://swa.co.id/businesschampions/companies/praktik-gcg-di-anak-usaha-bank-mandiri (diakses pada tanggal 17 Mei 2020, Jam, 11.25)

Kooiman J. 2009. Governing as Governance. SAGE.

Pawito. 2007. Penelitian Komunikasi Kualitatif. Yogyakarta(ID): Pelangi Aksara Yogyakarta

Peraturan Otoritas jasa Keuangan Nomor 73/POJK.05/2016 Tahun 2016. Tentang Tata Kelola Perusahaan Yang Baik

PT AXA Mandiri Financial Services. (2016) Annual Report AXA Mandiri. Retrieved May 15, 2020, from https://s.docworkspace.com/d/AJu5lsanlc03gsC5jvKmFA

Sugiyono. 2013. Metode Penelitian Pendidikan Pendekatan Kuantitatif, Kualitatif, dan R\&D. Bandung(ID): Alfabeta

Widodo D, Silitonga P, Ali H. 2020. The Influence of Good Governance, Culture, and Performance in Increasing Public Satisfaction and Implication to Public Trust: Study in Indonesian Government, Journal of Talent Development and Excellence. Vol.12, No.2 s, 2020, 843-854.

Zarkasyi, Moh. Wahyudi. 2008. Good Corporate Governance pada Badan Usaha Manufaktur, Perbankan dan Jasa Keuangan Lainnya. Bandung : Alfabeta

https://www.axa-mandiri.co.id/tentang-axa-mandiri/, (16 Mei 2020, Jam 17.45)

https://www.axa-mandiri.co.id/layanan-nasabah/informasi-umum/perkenalan-asuransi/, (16 Mei 2020, Jam 17.40)

https://axa.co.id/tentang-axa-indonesia/, , (15 Mei 2020, Jam 17.17) 